\title{
Konsep Force Majeure Dalam Akad Murabahah Dan Implementasinya Pada Lembaga Keuangan Syariah
}

\author{
Umdah Aulia Rohmah \\ Program Magister Ilmu Hukum Fakultas Hukum Universitas Islam Indonesia \\ Jln. Ci Di Tiro No. 1 Yogyakarta \\ jugayaya@gmail.com
}

\begin{abstract}
This study aims to determine and analyze the position of force majeure in murabahah contracts and how the implementation of force majeure in murabahah contracts in Sharia Financial Institutions. This study uses normative legal research supported by empirical data. Data collection techniques used by the author is the study of literature documents that are examined from books, literature, journals, and legislation. The conclusion of this research is first, the position of force majeure in the murabahah contract is a necessity to anticipate unwanted and dangerous circumstances, which are beyond the authority of the parties in the murabahah contract. In addition, Islamic law also regulates positions related to force majeure that is known as dharurah, which means damaging or giving harm. Second, the implementation of force majeure in the murabahah contract at the Sharia Financial Institution has already been applied in the contract or agreement by the parties. Force majeure clause becomes a reason not to charge the parties for losses arising from force majeure events that occur. Something that is allowed due to dharurah conditions, must be completed according to the required size restrictions.
\end{abstract}

Keywords: Force majeure; implementation; murabahah contract

\begin{abstract}
Abstrak
Penelitian ini bertujuan untuk mengetahui dan menganalisis kedudukan force majeure dalam akad murabahah dan bagaimana implementasi force majeure dalam akad murabahah pada Lembaga Keuangan Syariah. Penelitian ini menggunakan penelitian hukum normatif yang didukung oleh data empiris. Teknik pengumpulan data yang digunakan oleh penulis adalah studi dokumen kepustakaan yang ditelaah dari buku-buku, literatur-literatur, jurnal, dan perundang-undangan. Simpulan penelitian ini pertama kedudukan force majeure dalam akad murabahah sebagai suatu keharusan karena untuk mengantisipasi hal-hal yang tidak dikehendaki dan membahayakan, yang berada di luar kuasa dari para pihak dalam akad murabahah. Selain itu, Hukum Islam juga mengatur mengenai kedudukan yang berkaitan dengan force majeure yakni dikenal dengan istilah dharurah, yang berarti merusak atau memberi mudharat. Kedua, implementasi force majeure dalam akad murabahah pada Lembaga Keuangan Syariah pada perakteknya sudah diterapkan dalam akad atau perjanjian oleh para pihak. Klausula force majeure menjadi alasan untuk tidak membebankan kepada para pihak atas kerugian yang timbul akibat peristiwa force majeure yang terjadi. Sesuatu yang diperbolehkan karena kondisi dharurah, harus diselesaikan menurut batasan ukuran yang dibutuhkan.
\end{abstract}

Kata kunci: Force majeure; akad murabahah; implementasi 


\section{Pendahuluan}

Perbankan sebagai salah satu pilar pembangunan ekonomi Indonesia, mendapat perhatian serius oleh pemerintah dengan dikeluarkannya UndangUndang Nomor 14 Tahun 1967 tentang Pokok-Pokok Perbankan yang kemudian diubah dengan Undang-Undang Nomor 7 Tahun 1992 tentang Perbankan. Selanjutnya dilakukan perubahan kembali dengan Undang-Undang Nomor 10 Tahun 1998 tentang Perubahan Atas Undang-Undang Nomor 7 Tahun 1992 tentang Perbankan. ${ }^{1}$

Kegiatan perkreditan, sebagai salah sektor penting bank untuk masyarakat, harus mempertimbangkan beberapa hal untuk memperkecil resiko, yang terkait dengan iktikad baik (willingness to pay) dan kemampuan membayar (ability to pay) nasabah untuk melunasi kreditnya. ${ }^{2}$ Dalam analisis kredit tersebut dikenal dengan Prinsip 5C, yaitu 1) character (watak, sifat, kebiasaan debitur sangat berpengaruh pada pemberian kredit, 2) capacity (kapasitas berhubungan dengan kemampuan seorang debitur untuk mengembalikan pinjaman, 3) capital (kreditur dapat menilai modal debitur, semakin banyak modal yang ditanamkan, debitur akan dipandang semakin serius dalam menjalankan usahanya), 4) collateral (jaminan yang dibutuhkan untuk berjaga-jaga seandainya debitur tidak dapat mengembalikan pinjamannya serta terakhir 5) condition (kondisi ekonomi yang perlu diperhatikan antara lain masalah daya beli, masyarakat, 6) luas pasar, persaingan, perkembangan teknologi, bahan baku, pasar modal, dan sebagainya). ${ }^{3}$

Prinsip-prinsip tersebut juga berlaku dalam analisis pembiayaan syariah termasuk dalam akad murabahah, agar risiko kerugian dan tidak dilunasinya kredit dapat ditekan. Murabahah adalah jual beli barang pada harga dengan tambahan keuntungan/margin yang disepakati. ${ }^{4}$ Akad yang banyak mendapat penilaian tentang "kehalalan" pelaksanaannya adalah murabahah, yaitu jual beli dengan

${ }^{1}$ Munir Fuady, Hukum Perbankan Modern, Buku Kesatu, Citra Aditya Bakti, Bandung, 2003, hlm. 4

2 Ashofatul Lailiyah, "Urgensi Analisa 5C pada Pemberian Kredit Bank untuk Meminimalisir Resiko", Yuridika, Vol. 29 No. 2 Mei-Agustus 2014, hlm. 220

${ }^{3}$ Ibid., hlm. 224

4 Muhammad Safii Antonio, Bank Syariah Dari Teori Ke Praktek, Gema Insani Press, Jakarta, 2001, hlm 100 
harga jual terdiri dari harga beli dan keuntungan yang sudah disepakati. ${ }^{5}$ Dalam hal ini, murabahah dapat dilakukan dengan skema utang oleh Lembaga Keuangan Syariah (LKS) dapat menggunakan jaminan atasnya. ${ }^{6}$ Meskipun berdasarkan Prinsip 5C, LKS mempunyai langkah untuk mengantisipasi kerugian akibat nasabah yang tidak amanah, namun dalam keadaan tertentu, apakah kewajiban pelunasan hutang dalam akad murobahah mutlak hukumnya? Salah satunya dalam kondisi darurat/force majeure.

Force majeure merupakan salah satu konsep dalam hukum perdata dan diterima sebagai prinsip dalam hukum. Mochtar Kusumaatmadja menyatakan bahwa force majeure atau vis major dapat diterima sebagai suatu alasan untuk tidak memenuhi pelaksanaan kewajiban karena hilangnya objek atau tujuan yang menjadi pokok perjanjian. ${ }^{7}$ Keadaan ini ditujukan terhadap pelaksanaan secara fisik dan hukum, bukan dikarenakan hanya kesulitan dalam melaksanakan kewajiban. Mieke Komar Kantaatmadja memberikan pandangan senada yaitu: ${ }^{8}$

1. Perubahan suatu keadaan tidak terdapat pada waktu pembentukan perjanjian;

2. Perubahan tersebut perihal suatu keadaan yang fundamental bagi perjanjian tersebut;

3. Perubahan tersebut tidak dapat diperkirakan sebelumnya oleh para pihak;

4. Akibat perubahan tersebut haruslah radikal, sehingga mengubah luas lingkup kewajiban yang harus dilakukan menurut perjanjian itu;

5. Penggunaan asas tersebut tidak dapat diterapkan pada perjanjian perbatasan dan juga terjadinya perubahan keadaan akibat pelanggaran yang dilakukan oleh pihak yang mengajukan tuntutan.

Pembiayaan syariah sebagai bagian dari ekonomi syariah, maka dalam pendekatan force majeure juga harus dari sisi Hukum Islam. Force majeure adalah suatu keadaan yang memaksa yang dialami seorang. Dalam hukum Islam force majeure dikenal dengan istilah dharurah, yang diartikan sebagai keadaan yang mendesak yang mengancam eksistensi manusia dan di luar kemampuan manusia. Dharurah berkaitan dengan lima tujuan yang dikenal dalam hukum Islam sebagai

\footnotetext{
5 Ibid., hlm. 101

${ }^{6}$ Lihat Fatwa Dewan Syariah Nasional Nomor 04/DSN-MUI/IV/2000 tentang Murabahah poin keempat dan kelima.

${ }^{7}$ Susanto, Aspek-Aspek Hukum Perkreditan pada Bank, Jakarta, Alfabeta, 2003, hlm. 142-143.

${ }^{8}$ Harry Purwanto, Keberadaan Asas Rebus Sic Stantibus Dalam Perjanjian Internasional, Jurnal Mimbar Hukum Edisi Khusus, November 2011, hlm. 115.
} 
maqasid al-syariah (tujuan syariah), yaitu melindungi agama, jiwa, nasab, harta serta kehormatan manusia. Sehingga seseorang yang mengalami keadaan tersebut mendapatkan keringanan atau kemudahan sehingga memperbolehkan hal-hal yang awalnya dilarang untuk mengatasi permasalahan yang di hadapinya.

Penelitian ini lantas melihat adanya urgensi kajian atas kondisi force majeure atau dharurah yang dihadapi oleh nasabah LKS dalam akad murabahah sebelum menyelesaikan utangnya. Apakah lantas nasabah bebas dari utang murabahah atau mendapatkan keringanan? Penelitian ini mencoba untuk menggali akibat hukum atas terjadinya force majeure pada nasabah LKS dalam akad murabahah tersebut. Untuk menguatkan analisis penelitian ini, peneliti menggunakan data lapangan dari tiga LKS di wilayah Daerah Istimewa Yogyakarta.

\section{Rumusan Masalah}

Pertama, bagaimana kedudukan force majeure dalam akad murabahah? Kedua, bagaimana implementasi force majeure dalam akad murabahah pada Lembaga Keuangan Syariah (LKS)?

\section{Tujuan Penelitian}

Pertama, untuk mengetahui dan menganalisis kedudukan force majeure dalam akad murabahah. Kedua, bagaimana implementasi force majeure dalam akad murabahah pada Lembaga Keuangan Syariah (LKS).

\section{Metode Penelitian}

Penelitian ini merupakan penelitian hukum normatif dengan metode pengumpulan data studi pustaka. Bahan hukum yang digunakan yaitu 1) Bahan hukum primer, Undang-Undang Dasar Negara Republik Indonesia Tahun 1945, Kitab Undang-Undang Hukum Perdata, Undang-Undang Nomor 21 Tahun 2008 tentang Perbankan Syariah, Undang-Undang Nomor 21 Tahun 2011 tentang Otoritas Jasa Keuangan dan lain sebagainya berupa ketentuan hukum yang mengatur tentang perjanjian. 2) Bahan hukum sekunder, terdiri dari: buku, jurnal, artikel dan literatur lainnya yang berkaitan dengan permasalahan yang dibahas 
terkait dengan perjanjian, perbankan syariah. 3) Bahan hukum tersier, yaitu bahan yang memberikan petunjuk maupun penjelasan terhadap bahan hukum primer dan bahan hukum sekunder, yaitu ensiklopedia dan kamus, maupun juga bahan yang diperoleh dari internet.

Penelitian hukum normatif tersebut didukung dengan penelitian lapangan berupa wawancara dan mengumpulkan data klausul Force Majeure dalam akad murabahah pada Bank BCA Syariah KCU, Yogyakarta KCU Mangkubumi, Tamziz Baitul Maal Wat Tamwil Wates Kulonprogo (BMT), dan PT Bank Pembiayaan Rakyat Syariah UNISIA Insan Indonesia, Yogyakarta. Pengolahan dan analisis data yang digunakan adalah deskriptif-kualitatif. Dengan metode ini, masalah dan fakta akan digambarkan secara deskriptif, kemudian dianalisis guna memperoleh gambaran utuh tentang permasalahan-permasalahan yang diteliti. Data yang diperoleh melalui wawancara dengan narasumber kemudian dilakukan sinkronisasi dan dianalisis dengan peraturan atau literatur terkait.

\section{Hasil Penelitian dan Pembahasan}

\section{Kedudukan Force Majeure dalam Akad Murabahah}

Force majeure adalah suatu keadaan yang memaksa yang dialami seorang. ${ }^{9}$ Dalam Hukum Islam force majeure dapat dipersamakan dengan istilah dharurah. Dalam Hukum Islam dharurah diambil dari kata darra, yadurru dan darran yang memiliki arti merusak atau memberi mudharat. Dharurah adalah keadaan yang mendesak yang mengancam eksistensi manusia dan di luar kemampuan manusia yang berkaitan dengan panca (lima) tujuan yang dikenal dalam Hukum Islam yang dikenal sebagai maqasid al-syariah. Maqashid al-syariah mencakup perlindungan terhadap agama, jiwa, nasab, harta serta kehormatan manusia, sehingga seseorang yang mengalami hal tersebut mendapatkan keringanan atau kemudahan sehingga memperbolehkan hal-hal yang dilarang untuk mengatasi keadaan dharurah

${ }^{9}$ Ridho Rokamah, Al-Qawaid Al-Fiqhiyah Kaidah-Kaidah Mengembangkan Hukum Islam, Stain Press, Ponorogo, 2010, hlm. 52 
tersebut. ${ }^{10}$ Adapun penjelasan mengenai maqasid al-syariah dalam tingkatan dharuriyat sebagai berikut: ${ }^{11}$

1. Memelihara agama (hifdzu din), yaitu memelihara dan melaksanakan kewajiban keagamaan yang termasuk peringkat primer, seperti melaksanakan shalat lima waktu. Bila shalat ini diabaikan, maka eksistensi agama akan terancam.

2. Memelihara jiwa (hifdzu nafs), yaitu memenuhi kebutuhan pokok berupa makanan untuk mempertahankan hidup, jika kebutuhan pokok diabaikan maka akan terancam eksistensi jiwa manusia.

3. Memelihara akal (hifdzu aql) yaitu diharamkannya minum-minuman keras, apabila ketentuan ini dilanggar maka akan terancam eksistensi akal manusia.

4. Menjaga keturunan (hifdzu nasl), yaitu disyaratkannya menikah dan dilarang berzina. Apabila hal tersebut dilanggar maka akan terancam eksistensi keturunannya.

5. Menjaga harta (hifdzu maal), yaitu seperti disyariatkannya tatacara kepemilikan melalui jual beli dan dilarangnya mengambil harta orang lain dengan bathil seperti mencuri, riba dan lain-lain. Apabila dilanggar maka akan terancam eksistensi hartanya.

Kedudukan force majeure dalam Hukum Islam berbeda dengan hukum perdata. Dalam hukum Islam kedudukan force majeure didasarkan kepada sesuatu hal yang dapat mengancam maqasid al- syariah seperti yang telah diuraikan berdasarkan pengertian force majeure dalam Hukum Islam. Batasan force majeure menurut Hukum Islam dengan hukum perdata.

Kaidah-kaidah Islam yang menggambarkan keadaan force majeure di antaranya masaqat (kesulitan) bisa menarik kemudahan. ${ }^{12}$ Maksudnya adalah bahwa hukum-hukum yang dalam penerapannya menimbulkan kesulitan dan kesukaran bagi pelaku, yang dalam hal ini adalah seorang mukallaf, maka syariat meringankannya sehingga orang mukallaf tersebut bisa melaksanakannya tanpa merasa kesulitan. Seperti halnya kesulitan orang yang sakit untuk melaksanakan

${ }^{10}$ Ibid., hlm. 3

11 Suhaeri, "Putusan Mahkamah Konstitusi Menghapus Rintisan Sekolah Bertaraf Internasional dalam Tinjauan Maqashid Syari'ah”, Jurnal Konsitusi, Vol. 10 No. 2 Juni 2013, hlm. 365 - 367

${ }^{12}$ H. Abbas Arfan, 99 Kaidah Fiqh Muamalah Kulliyah, Cetakan II, UIN Maliki Pers, Malang, 2013, hlm. 154 
shalat dengan berdiri maka bisa dengan duduk, apabila tidak bisa duduk maka dengan cara berbaring. ${ }^{13}$

Kaidah di atas ini menjadi sumber adanya keringanan dalam menjalankan tuntutan syariat diantaranya seperti keringanan yang diberikan karena keadaan terpaksa serta unsur kurang mampu dan kesukaran umum yang menjadi akibat terjadinya force majeure. Kaidah tersebut merupakan hasil modifikasi dari QS. Al Baqarah: 185, QS. Al Hajj: 78, QS. An Nisa: 28, QS. Al Baqarah: 286, yang seluruh ayatnya tersebut menunjukkan kemudahan dan keringanan yang diberikan oleh Allah kepada hamba-Nya. Ayat-ayat Al-qur'an tersebut menjelaskan mengenai keringanan bagi orang yang sakit atau dalam perjalanan diperbolehkan untuk tidak berpuasa, namun tetap berkewajiban untuk menggantinya sebanyak puasa yang ditinggalkannya. Substansi dari ayat di atas adalah Allah tidak akan mempersulit hamba-Nya dalam beribadah. Selain kaidah tersebut, terdapat juga kaidah lain yang sama dengan kaidah di atas yakni kemudaratan (bahaya) harus dihilangkan, hanya saja kaidah ini lebih kepada kewajiban menghilangkan madarat setelah madarat itu terjadi (upaya pengobatan). ${ }^{14}$

Sementara itu, di dalam literatur figh klasik, terdapat sebuah ketentuan hukum yang hampir menyerupai force majeure. Ketentuan ini biasa disebut dengan al-Jaihah, yaitu suatu keadaan dimana telah terjadi akad salam antara petani buah dan pembeli. Keduanya sepakat bahwa jika buah-buahan tersebut telah siap panen, maka petani menyerahkannya kepada pembeli sesuai dengan harga yang telah diterima oleh petani. Ketika hanya nampak beberapa buah yang matang, namun terjadi suatu bencana di luar kekuasaan keduanya yang memaksa petani tidak dapat menyerahkan hasil panennya. Atau bisa disimpulkan al jaihah adalah bencana yang biasa berlaku pada buah-buahan, yang menyebabkan kerusakan dan kemusnahan padanya. ${ }^{15}$ Sejatinya al-jaihah dalam penerapannya tidaklah terbatas pada akad salam, melainkan dapat di-qiyas-kan kepada beberapa akad, diantaranya ijrah, ba'i murabahah, isthisna' dan sebagainya.

13 Ibid., hlm. 154

14 Ibid, hlm. 155

15 Zaharuddin Abd. Rahman, Fiqh Kewangan Islam, PTS Islamika, Malaysia, 2014, hlm. 597 
Pasal 40 Kompilasi Hukum Ekonomi Syariah (KHES) dijelaskan mengenai keadaan memaksa bahwa yang dimaksud dengan force majeure adalah keadaan dimana salah satu pihak yang mengadakan akad terhalang untuk melaksanakan perestasinya. ${ }^{16}$ Kemudian dalam Pasal 41 dijelaskan mengenai syarat-syarat peristiwa yang termasuk keadaan memaksa yakni, peristiwa tersebut haruslah peristiwa yang tidak dapat diduga sebelumnya, peristiwa tersebut tidak harus dipertanggungjawabkan kepada pihak yang harus memenuhi prestasi, peristiwa terjadi di luar kesalahan si pihak yang harus memenuhi prestasi dan yang terakhir pihak yang harus memenuhi prestasi tersebut tidak beritikad buruk. ${ }^{17}$

Pasal 42 menjelaskan mengenai risiko yakni, kewajiban memikul kerugian yang tidak disebabkan oleh kesalahan salah satu pihak disebut sebagai risiko. ${ }^{18}$ Kemudian dalam Pasal 43 dijelaskan lebih lanjut mengenai risiko tersebut, yakni kerugian yang disebabkan oleh kejadian di luar salah satu pihak dalam akad perjanjian sepihak dipikul oleh pihak peminjam, sedangkan kerugian yang disebabkan oleh kejadian di luar salah satu pihak dalam akad perjanjian timbal balik dipikul oleh pihak yang meminjamkan. ${ }^{19}$

Melihat Fatwa Dewan Syariah Majelis Ulama Indonesia (MUI) sebenarnya tidak ada aturan yang secara tegas dan khusus menjelaskan mengenai force majeure dalam Fatwa Dewan Syariah MUI. Namun terdapat beberapa fatwa yang sedikit menyinggung dan berkaitan dengan force majeure. Fatwa Dewan Syariah Majelis Ulama Indonesia Nomor 48/DSN-MUI/II/2005 tentang Penjadwalan Kembali Tagihan Murabahah pada dasarnya menetapkan Fatwa Tentang Penjadwalan Kembali Tagihan Murabahah, dimana LKS boleh melakukan penjadwalan kembali tagihan murabahah bagi nasabah yang tidak bisa menyelesaikan/melunasi pembiayaannya sesuai jumlah dan waktu yang telah disepakati, dengan ketentuan tidak menambah jumlah tagihan yang tersisa, pembebanan biaya dalam proses penjadwalan kembali biaya riil, perpanjangan masa pembayaran harus

\footnotetext{
${ }^{16}$ Pasal 40 Kompilasi Hukum Ekonomi Syariah (KHES)

${ }^{17}$ Pasal 41 Kompilasi Hukum Ekonomi Syariah (KHES)

${ }^{18}$ Pasal 42 Kompilasi Hukum Ekonomi Syariah (KHES)

19 Pasal 43 Kompilasi Hukum Ekonomi Syariah (KHES)
} 
berdasarkan kesepakatan kedua belah pihak. Jika salah satu pihak tidak menunaikan kewajibannya atau jika terjadi perselisihan di antara pihak-pihak terkait, maka penyelesainnya dilakukan melalui Badan Arbitrase Syariah Nasional setelah tidak tercapai kesepakatan melalui musyawarah. Fatwa ini berlaku sejak tanggal ditetapkan dengan ketentuan jika di kemudian hari ternyata terdapat kekeliruan, akan dirubah dan disempurnakan sebagaimana mestinya.

Fatwa Dewan Syariah MUI Nomor 17/DSNMUI/IX/2000 tentang Sanksi Atas Nasabah Mampu Yang Menunda-nunda Pembayaran pada intinya menetapkan fatwa tenang sanksi atas nasabah mampu yang menunda-nunda pembayaran. Sanksi yang disebut dalam fatwa ini adalah sanksi yang dikenakan LKS kepada nasabah yang mampu membayar, tetapi menunda-nunda pembayaran dengan disengaja. Nasabah yang tidak/belum mampu membayar disebabkan force majeure tidak boleh dikenakan sanksi. Nasabah mampu yang menunda-nunda pembayaran dan/atau tidak mempunyai kemauan dan itikad baik untuk membayar hutangnya boleh dikenakan sanksi. Sanksi didasarkan pada prinsip ta'zir, yaitu bertujuan agar nasabah lebih disiplin dalam melaksanakan kewajibannya. Sanksi dapat berupa denda sejumlah uang yang besarnya ditentukan atas dasar kesepakatan dan dibuat saat akad ditandatangani. Dana yang berasal dari denda diperuntukkan sebagai dana sosial. Jika salah satu pihak tidak menunaikan kewajibannya atau jika terjadi perselisihan di antara pihakpihak terkait, maka penyelesainnya dilakukan melalui Badan Arbitrase Syariah Nasional setelah tidak tercapai kesepakatan melalui musyawarah. Fatwa MUI tersebut berlaku sejak tanggal ditetapkan dengan ketentuan jika di kemudian hari ternyata terdapat kekeliruan, akan dirubah dan disempurnakan sebagaimana mestinya.

Perihal terjadinya force majeure dalam akad murabahah ialah beragam. Menurut pembagiannya, force majeure sendiri dibagi menjadi 3 (tiga) bagian, yakni:20

\footnotetext{
OJK, "Standar Produk Perbankan Syariah Murabahah", diakses dari https://www.ojk.go.id/id/kanal/syariah/berita-dan-kegiatan/publikasi/Documents/Pages/Buku-StandarProduk-Perbankan-Syariah-Murabahah/Buku\%20Standar\%20Produk\%20Murabahah.pdf pada tanggal 13 Juli 2019 pukul $20: 11$ WIB
} 
1. Menurut Jenisnya

a. Force majeure objektif

Force majeure ini terjadi pada benda yang merupakan objek dari kontrak sehingga prestasi tidak mungkin dipenuhi lagi, tanpa adanya kesalahan dari pihak debitur.

b. Force majeure subjektif

Force majeure ini berhubungan dengan keadaan atau kemampuan dari debitur itu sendiri. Misalnya, jika debitur sakit atau cacat seumur hidup sehingga tidak mungkin lagi melakukan prestasi.

2. Menurut Pelaksanaannya

a. Force majeure absolut

Suatu keadaan dimana debitur sama sekali tidak dapat memenuhi kewajibannya kepada kreditur dikarenakan bencana alam atau act of God yang bersifat mutlak, misalnya karena adanya gempa bumi, banjir bandang, dan adanya lahar dan lain-lain.

b. Force majeure relatif

Dalam force majeure ini, pemenuhan prestasi secara normal tidak mungkin dilakukan, walaupun secara tidak normal masih mungkin dilakukan. Force majeur ini disebut juga act of nature yang dapat disimpulkan peristiwa ini tidak bersifat mutlak atau relatif.

3. Menurut Jangka Waktu Berlakunya

a. Force majeure permanen

Yakni efek terjadinya force majeure sampai kapanpun kontrak tidak akan mungkin dilakukan lagi untuk memenuhi suatu prestasi kontrak yang telah dijanjikan. Misalnya jika barang yang merupakan objek dari kontrak tersebut musnah di luar kesalahan salah satu pihak.

b. Force majeure temporer

Dimana terhadap pemenuhan prestasi dari kontrak tersebut tidak mungkin dilakukan untuk sementara waktu. Atau dengan kata lain, karena terjadi peristiwa tertentu dimana setelah peristiwa tersebut berhenti, prestasi tersebut dapat dipenuhi kembali.

Umumnya, setiap permohonan pembiayaan murabahah, bank akan menerangkan esensi dari pembiayaan murabahah, serta kondisi penerapannya. Salah satu yang diterangkan adalah tentang definisi atas kondisi force majeure yang dapat dijadikan dasar acuan bahwa bank tidak akan mengalami kerugian (dirugikan) oleh faktor-faktor yang bersifat spesifik. ${ }^{21}$ Hal ini berbeda dengan ketentuan force majeure yang diatur di dalam KUHPerdata maupun di dalam

${ }^{21}$ Ascarya, Akad \& Produk Bank Syariah, Raja Grafindo Persada, Jakarta, 2011, hlm. 238 
Kompilasi Hukum Ekonomi Syariah (KHES). Pengaturan tentang force majeure di dalam KUHPerdata diatur dalam Pasal $1244^{22}$ dan Pasal 1245.23

Menurut V. Brakel, dengan adanya overmacht/ force majeure, menyebabkan kewajiban prestasi debitur menjadi hapus dan konsekuensi lebih lanjut adalah debitur tidak perlu mengganti kerugian kreditur yang diakibatkan oleh adanya keadaan memaksa. ${ }^{24}$ Sedangkan menurut KHES, yakni pada pasal 43 ayat 1 , yang rumusannya sebagai berikut, "kewajiban menanggung kerugian yang disebabkan kejadian di luar kesalahan salah satu pihak dalam perjanjian sepihak dipikul oleh peminjam", kemudian ayat selanjutnya, "kewajiban menanggung kerugian yang disebabkan kejadian di luar kesalahan salah satu pihak dalam perjanjian timbal balik, dipikul oleh pihak yang meminjamkan". 25

Berdasarkan hal di atas, keberadaan sarana dan mekanisme penanganan terhadap pembiayaan bermasalah merupakan hal yang penting untuk diketahui oleh nasabah sebagai upaya perlindungan terhadap nasabah, serta sebagai upaya untuk menghindari konflik lebih lanjut yang dapat menimbulkan kerugian bagi nasabah maupun bank.

Menurut Buku Standar Produk Perbankan Syariah Murabahah, yang diterbitkan oleh OJK, penyelesaian sengketa pada kasus pembiayaan muarbahah bermasalah memiliki beberapa tahapan, yaitu: ${ }^{26}$

1. Pengaturan mengenai penyelesaian sengketa antara pihak Bank dengan nasabah harus mengutamakan prinsip musyawarah mufakat;

2. Mekanisme musyawarah dilakukan dengan tujuan untuk memberikan solusi yang dianggap sesuai dengan kemampuan dan kondisi nasabah yang terkena force majeure;

3. Beberapa solusi yang ditawarkan bank dalam mekanisme musyawarah kepada nasabah seperti perpanjangan waktu pembayaran angsuran, perubahan jumlah angsuran, pemberian tambahan kredit, dsb;

22 "Debitur harus dihukum untuk mengganti biaya, kerugian dan bunga. Bila ia tak dapat membuktikan bahwa tidak dilaksanakannya perikatan itu atau tidak tepatnya waktu dalam melaksanakan perikatan itu disebabkan oleh sesuatu hal yang tak terduga, yang tak dapat dipertanggungkan kepadanya. Walaupun tidak ada itikad buruk kepadanya."

23 "Tidak ada penggantian biaya. kerugian dan bunga. Bila karena keadaan memaksa atau karena hal yang terjadi secara kebetulan, debitur terhalang untuk memberikan atau berbuat sesuatu yang diwajibkan, atau melakukan suatu perbuatan yang terlarang baginya."

${ }^{24}$ J. Satrio, Hukum Perikatan Perikatan pada Umumnya, Alumni, Bandung, 1999, hlm. 249

25 Peraturan Mahkamah Agung Republik Indonesia Nomor 02 Tahun 2008 tentang Kompilasi Hukum Ekonomi Syariah, Pasal 43 ayat (1 dan 2).

${ }^{26}$ OJK, "Standar Produk Perbankan Syariah Murabahah", Op.Cit 
4. Apabila mekanisme musyawarah belum berhasil, penyelesaian sengketa dapat dilakukan secara non litigasi misalnya melalui Badan Arbitrase Syariah Nasional (Basyarnas) dan eksekusi atau putusan arbitrase syariah itu akan ditetapkan melalui Pengadilan Agama;

5. Apabila para pihak menyepakati untuk menyelesaikan sengketa melalui pengadilan, maka Bank dan Nasabah harus menyepakati dalam kontrak bahwa kewenangan untuk mengadili sengketa kontrak ini diselesaikan melalui Pengadilan Agama;

6. Pihak Bank tidak diperkenankan menuliskan klausula dalam kontrak yang membolehkan Bank melakukan eksekusi agunan dan jaminan secara langsung sesaat setelah terjadi tunggakan ataupun wanprestasi tanpa putusan pengadilan;

7. Pihak Bank tidak diperkenankan melakukan eksekusi agunan dan jaminan secara langsung sesaat setelah terjadi tunggakan ataupun wanprestasi sebelum ada putusan pengadilan yang menyatakan bahwa Nasabah lalai dan memberikan hak kepada Bank untuk eksekusi agunan dan jaminan;

8. Jika sampai tahap eksekusi agunan obyek pembiayaan dan/atau jaminan lainnya dilakukan, maka hasil eksekusi (penjualan/pelelangan) tersebut diutamakan untuk memenuhi kewajiban Nasabah kepada Bank. Jika ada kelebihan nilai eksekusi maka dikembalikan ke Nasabah, jika masih kurang untuk memenuhi hak Bank maka hal itu tetap menjadi kewajiban Nasabah hingga Bank menghapuskan kewajiban tersebut.

Berakhirnya akad murabahah dapat disebabkan oleh berakhirnya jangka waktu akad, peristiwa force majeure, cidera janji, dan nasabah yang mengajukan pengakhiran akad murabahah. Akad ini dinyatakan berakhir apabila telah dipenuhinya kewajiban oleh para pihak dalam kontrak yang termasuk meliputi hal-hal berikut: 27

1. Terpenuhinya keseluruhan kewajiban atas harga jualmurabahah;

2. Adanya peralihan atau transfer atas kewajiban membayar harga jual murabahahkepada pihak ketiga melalui akad (hiwalah);

3. Bank melepaskan hak untuk menerima pembayaran harga jual melalui pemberian potongan harga ( $\left.i b r a^{\prime}\right)$;

4. Bank memberikan potongan margin pembiayaan (Muqasah) atas kewajiban murabahah nasabah;

5. Masing masing pihak dalam kontrak bersepakat untuk mengakhiri kontrak dalam periode jangka waktu kontrak yang telah disepakati;

6. Salah satu pihak dalam kontrak memutuskan untuk mengakhiri kontrak dikarenakan adanya wanprestasi oleh pihak lain;

7. Kedua belah pihak menyepakati untuk mengakhiri akad murabahah; 
8. Terdapat cacat, kerusakan, atau aib pada obyek barang yang akan dijual ketika diserahkan kepada penjual;

9. Obyek hilang atau musnah, baik karna force majeure atau wanprestasi;

10. Tenggang waktu yang disepakati dalam akad murabahah telah berakhir, baik cara pembayarannya secara sekaligus ataupun secara angsuran.

Dalam pengakhiran akad murabahah, perihal force majeure dapat dilihat pada poin 9 yang menyatakan jika objek pada perjanjian akad murabahah hilang atau musnah dikarenakan force majeure dan tidak ada itikad buruk padanya maka perjanjian akad murabahah diantara para pihak dapat saja berakhir.

\section{Implementasi Force Majeure dalam Akad Murabahah pada Lembaga Keuangan Syariah (LKS)}

Kedudukan force majeure dalam akad murabahah di setiap bank mempunyai konsep dan pengaturan yang berbeda antara satu bank dengan bank lainnya. Untuk mendukung pernyataan ini, Penulis telah melakukan wawancara dengan beberapa Bank Syariah di Yogyakarta, dan telah ditemukan beberapa hasil sebagai berikut.

Pertama, berdasarkan hasil wawancara Penulis dengan Bapak Aryo Bramasto selaku ASO Account Officer Bank BCA Syariah KCP Mangkubumi, 28 bahwa Bank BCA Syariah telah berdiri sejak tahun 2010, sedangkan untuk cabang Jogja sudah berdiri sejak tahun 2015. Selama berdirinya cabang Jogja telah banyak melakukan akad murabahah dengan berbagai nasabah, dimana setiap akad murabahah antara bank dengan nasabah pasti menyantumkan klausal mengenai force majeure disesuaikan dengan jenis akad murabahah nya. Namun sejak tahun 2015, Bank BCA Syariah KCP Mangkubumi dalam melakukan akad murabahah dengan nasabah tidak pernah mengalami force majeure baik terhadap objek akad maupun jaminan/anggunan. Adapun mengenai isi dari ketentuan force majeure tersebut dibuat di pusat (Jakarta) kemudian Bank KCP Mangkubumi hanya mencetak saja klausal tersebut kemudian diserahkan kepada nasabah dan dijelaskan kembali sebelum penandatanganan kerjasama akad murabahah.

${ }^{28}$ Hasil wawancara dengan Bapak Aryo Bramasto (ASO Account Officer) Bank BCA Syaiah KCU Yogyakarta, KCP Mangkubumi, Pada Hari Senin 8 Juli 2019, Pukul 10:21 WIB 
Akad murabahah antara pihak bank dengan nasabah ada beberapa contoh akad murabahah yang telah dilakukan seperti, akad murabahah dengan nasabah yang akan membeli sebuah pabrik, maka objek yang dibeli tersebut dijaminkan dan diasuransikan yang kemudian ada pihak ketiga yaitu perusahaan asuransi syariah yang mengcover objek jaminan tersebut. Namun, nasabah diberikan opsi kedua jika keberatan dengan opsi tersebut yakni jika nasabah mempunyai bisnis yang bagus kemudian bias didelegasikan ke anaknya yang preminya cukup besar. Selain menjaminkan objek dari akad murabahah tersebut nasabah juga bisa menjaminkan hartanya. Contoh, akad murabahah terkait jual beli stok pasir dan batu bata, namun yang diasuransikan adalah rumah nasabah yang kemudian menjadi jaminan.

Adapun jenis force majeure apa saja yang dicantumkan dalam klausal akad murabahah dengan nasabah tidak bisa didapatkan oleh Penulis karena dari pihak bank yang tertutup dengan alasan kebijakan kantor dan demi kepentingan nasabah. Selanjutnya jika terjadi force majeure terhadap objek jaminan atau objek akad murabahah pada saat pelaksanaan akad murabahah akan dilakukan beberapa pendekatan awal, diantaranya: ${ }^{29}$

a. Jika force majeure terkait objek murabahah kategori ringan, dari pihak bank akan berkomunikasi dengan nasabah apakah nasabah masih mampu melaksanakan kewajibannya, jika masih mampu maka pihak bank akan membantu untuk mengurus asuransi jika diperlukan.

b. Jika force majeure sedang, Bank KCP Mangkubumi akan melakukan konfirmasi ke pusat kemudian dari pusat akan memberikan 3 (tiga) kebijakan diantaranya, memberikan keringanan angsuran, pengembalian angsuran atau pemotongan angsuran. Namun jika masih bisa di-cover oleh pihak asuransi maka asuransi akan ikut mem-back up objek nasabah yang diasuransikan tersebut.

c. Jika force majeure berat/besar yang membuat bisnis nasabah tidak bisa berjalan lagi, maka dari pihak bank dengan sisi pengajuan dari nasabah sendiri dilanjutkan ke pusat minta keringanan, karena nasabah tidak mampu lagi melaksanakan atau melunasi pembayarannya maka akan diberikan waktu sampai batas tertentu dengan keringanan-keringanan yang dikeluarkan oleh pusat. Apabila sampai batas yang sudah ditentukan masih tidak mampu melunasi dan tidak bertemunya kata sepakat antara pihak bank dan nasabah, maka untuk membayar/melunasi pembayaran nasabah yang bersangkutan maka pusat akan bekerjasama dengan bagian litigasi 
penanganan kredit bermasalah dengan dilihat pendekatan-pendekatan yang bisa dilakukan kemudian dilakukan penjualan terhadap agunannya atau dilelang selama jaminan atau agunannya tidak terkena dampak force majeure. Namun, jika terkena dampak force majeure, dari pihak bank akan melakukan klaim asuransi yang dimana nilai asuransi tersebut sudah bisa meng-cover pinjaman nasabah.

Menurut Bapak Aryo Bramasto, pendekatan terhadap nasabah itu berbedabeda, tergantung kasus yang dihadapi dan seberapa besar nominal perjanjian maupun besaran kasus yang dihadapi. Selama nasabah mempunyai itikad baik dan terbuka kepada pihak bank, pihak bank pasti akan memberikan solusi yang terbaik dengan pendekatan-pendekatan secara person to person..$^{30}$

Kedua, Tamziz Baitul Maal Wat Tamwil (selanjutnya disebut BMT) Wates Kulon Progo. ${ }^{31}$ BMT adalah lembaga keuangan dengan konsep syariah yang lahir sebagai pilihan dalam satu kegiatan lembaga. Kehadiran BMT sebagai lembaga keuangan mikro dirasa telah membawa manfaat untuk finansial masyarakat terutama bagi masyarakat kecil yang tidak ingin atau menolak riba.

Penulis melakukan wawancara dengan Bapak Bambang selaku Managemen Marketing BMT dan Ibu Warimah selaku nasabah BMT yang berprofesi sebagai pedagang pakaian anak dan mainan anak di Pasar Umum Bendungan Wates Kulonprogo.32 Pada Februari 2016 lalu BMT dan ibu Warimah melakukan akad murabahah untuk pembelian pakaian anak dan mainan anak sejumlah Rp. 5.000.000,00 dengan model-model dan jenis katalog atau gambar yang disediakan oleh Ibu Warimah selaku nasabah, yang mana tujuan pembelian barang tersebut untuk bisnis yaitu dijual kembali oleh ibu Warimah di Pasar Umum Bendungan Wates Kulonprogo. Pada Selasa 19 April 2016 lalu terjadi kebakaran di Pasar Umum Bendungan Wates Kulonprogo, yang mengakibatkan toko atau lapak Ibu Warimah ikut terbakar yang kemudian mengakibatkan seluruh dagangan yang berupa pakaian anak dan mainan anak milik Ibu Warimah habis terbakar.

\footnotetext{
${ }^{30}$ Ibid

${ }^{31}$ Hasil wawancara dengan Baitul Maal Wat Tamwil, Wates Kulonprogo tanggal 6 Juli 2019, Pukul 09 : 12 WIB

32 Wawancara dengan Bapak Bambang selaku Managemen Marketing BMT dan Ibu Warimah selaku nasabah BMT, Wates Kulonprogo tanggal 6 Juli 2019, Pukul 09 : 12 WIB
} 
Barang dagangan milik Ibu Warimah yang terbakar tersebut, 30 persen dari seluruh barang yang terbakar adalah barang yang dibeli dengan modal yang didapatkan dari hasil akad murabahah dengan BMT pada Januari 2016 lalu. Adapun penyebab terjadinya kebakaran tersebut menurut keterangan petugas pasar bapak Agus dikarenakan arus listrik yang konslet dibagian kios B.

Saat Ibu Warimah dan BMT melakukan akad murabahah, Ibu Warimah mengasuransikan objek murabahah tersebut. Menurut Bapak Bambang selaku managemen marketing BMT, jika nominal pinjaman di bawah Rp. 50.000.000,00 maka akan diasuransikan oleh BMT sendiri dengan pembayaran asuransi sebesar Rp. 7.000,00. Akibat dari kebakaran tersebut ibu Warimah mengalami kerugian hampir Rp. 20.000.000,00. Setelah dilakukan pengecekan lokasi oleh pihak asuransi dari pihak BMT sendiri, pada awal Mei 2016 lalu, BMT melakukan pemutihan atau menghapus sisa pembayaran pinjaman Ibu Warimah di BMT.

Berdasarkan kasus di atas, Penulis mengutip pendapat Mariam Darus Badrulzaman dalam bukunya yang menyebutkan bahwa tidak dapat dilaksanakannya kewajiban debitur (kredit macet) yang diakibatkan oleh force majeure yang dalam hal ini adalah unsur ketidaksengajaan yang kemudian diartikan bahwa debitur bersedia membayar namun tidak mampu. ${ }^{33}$ Peristiwa tersebut merupakan keadaan memaksa yang terjadi di luar kesalahan Ibu Warimah selaku debitur setelah adanya penutupan perjanjian, yang menghalangi Ibu Warimah memenuhi prestasinya, maka Ibu Warimah tidak dapat disalahkan sekaligus tidak menanggung resiko dari terjadinya peristiwa tersebut.

Mariam Darus Badrulzaman menjelaskan, terdapat tiga unsur yang seharusnya dipenuhi untuk dapat dikategorikan sebagai keadaan memaksa, diantaranya :34

a. Tidak terpenuhinya prestasi akibat terjadinya peristiwa memusnahkan atau membinasakan benda yang menjadi objek perikatan;

b. Ada sebab yang berada di luar kesalahan debitur akibat terjadinya peristiwa yang menjadi pengahalang bagi tindakan debitur untuk berprestasi;

${ }^{33}$ Mariam Darus Badrulzaman, Perjanjian Kredit Bank, Citra Aditya Bakti, Bandung, 1991, hlm. 68

${ }^{34}$ Ibid., hlm. 68 
c. Faktor penyebab yang muncul tidak dapat diduga sebelumnya, selain itu tidak dapat untuk dipertanggungjawabkan pada debitur.

Mahkamah Agung melalui putusannya No. 409K/Sip/1983 telah memberi pernyataan bahwa keadaan yang memaksa dapat dilihat sebagai kondisi yang diakibatkan oleh suatu malapetaka yang secara patut memang tidak dapat dicegah oleh pihak yang berprestasi sekalipun. Bahkan jauh sebelum munculnya putusan seperti di atas, dalam putusan Mahkamah Agung No. 24K/Sip/1958 juga menyatakan bahwa force majeure sudah menutup adanya kemungkinankemungkinan maupun alternatif lainnya untuk pihak yang terkena force majeure guna memenuhi kontrak. Pasal 91 ayat (2) Peraturan Presiden Nomor 54 Tahun 2010 tentang Pengadaan Barang/Jasa Pemerintah menjelaskan bahwa kebakaran termasuk dalam kategori keadaan kahar.

Kebakaran Pasar Umum Bendungan Wates Kulonprogo dapat disimpulkan sebagai keadaan memaksa sehingga jika mengacu kepada pendapat ahli di atas serta peraturan-peraturan terkait, bahwa terhalangnya ibu Warimah untuk melakukan prestasi dikarenakan keadaan memaksa yang berada di luar keinginan atau kehendak ibu Warimah (force majeure objektif).

Ketiga, PT. Bank Pembiayaan Rakyat Syariah UNISIA Insan Indonesia ${ }^{35}$ (selanjutnya disebut sebagai bank/penjual), dan Bapak Muhammad Natsir Usamah (selanjutnya disebut sebagai nasabah/pembeli), menghadap kepada Supatmi, Notaris di Sleman. Bahwa keduanya akan melaksanakan transaksi murabahah, yang mana bank akan menjual kepada nasabah barang yang akan dibeli dari pemasok sesuai dengan pesanan nasabah dan nsaabah akan membeli barang tersebut sesuai dengan yang dipesankan kepada bank.

Bank telah memberikan fasilitas pembiayaan kepada nasabah sebesar Rp. 290.000.000,00, sebagaimana yang termuat dalam akad pembiayaan murabahah dengan nomor 74, tertanggal 22 Maret 2017 yang dibuat di hadapan Notaris Supatmi, S.H Mkn dengan outstanding/baki debet sebesar Rp. 280.000.000,00. Dalam akad tersebut, nasabah mengajukan permohonan restrukturisasi

35 Hasil wawancara dengan PT Bank Pembiayaan Rakyat Syariah UNISIA Insan Indonesia, Yogyakarta, tanggal 5 Juli 2019, Pukul $10: 20$ WIB 
pembiayaan tersebut sesuai dengan kesepakatan para pihak. Bahwa restrukturisasi fasilitas pembiayaan menjadi satu kesatuan yang tidak terpisahkan dengan akad pembiayaan murabahah sebelumnya. ${ }^{36}$

Pokok akad, bank berjanji dan mengikat diri untuk menjual barang yang dipesan oleh nasabah dan menyerahkannya kepada nasabah, dan nasabah dengan ini berjanji dan mengikat diri untuk membeli dan menerima barang serta membayar harganya kepada bank. Objek akad murabahah tersebut adalah pembelian furnitur dan interior exclusive $\mathcal{E}$ guesthouse Bale Seturan. Pada ketentuan pokok akad harga beli sebesar Rp. 280.944.721,00 dengan keuntungan/margin sebesar Rp. 165.647.341,00 dengan harga jual Rp. 446.592.062,00 dan utang murabahah sebesar Rp. 446.592.062,00.

Jangka waktu akad murabahah selama 57 bulan terhitung sejak 22 Nopember 2017 dan jatuh tempo pada 22 September 2022. Untuk lebih menjamin pembayaran kembali utang murabahah dengan tertib dan secara sebagaimana mestinya oleh nasabah kepada bank, maka nasabah menjaminkan barang kepada bank berupa sebidang tanah pekarangan berdasarkan sertipikat hak milik nomo 4733/Sukoharjo, seluas $1.182 \mathrm{~m}^{2}$ sesuai dengan surat ukur Nomor 00813, 25 Mei 2001, yang terletak di Desa/Kelurahan Sukoharjo, Kecamatan Ngaglik Kabupaten Sleman, DIY atas nama Murdiharjo/Rukiman.

Akad murabahah di atas, para pihak mencantumkan klausul force majeure sebagai berikut:

a. Force majeure yaitu peristiwa-peristiwa yang disebabkan oleh bencana alam, kerusuhan, huru hara, pemberontakan, epidemic, sabotase, peperangan, pemogokan, kebijakan pemerintah atau sebab lain diluar kekuasaan nasabah dan bank;

b. Dalam hal terjadi force majeure, maka pihak yang terkena langsung akibat force majeure tersebut wajib memberitahukan secara tertulis dengan melampirkan bukti-bukti dari kepolisian/instansi yang berwenang kepada pihak lainnya mengenai peristiwa force majeure tersebut dalam waktu selambat-lambatnya empat belas hari terhitung sejak tanggal force majeure ditetapkan;

${ }^{36}$ Lihat Akta Akad Pembiayaan Murabahah (addendum 1) Nomor 58 Tahun 2017, Notaris Supatmi, S.H, M.Kn 
c. Keterlambatan atau kelalaian para pihak untuk memberitahukan adanya force majeure tersebut mengakibatkan tidak diakuinya peristiwa tersebut sebagai force majeure oleh pihak lain;

d. Segala tiap-tiap permasalahan yang timbul akibat terjadinya force majeure akan diselesaikan oleh nasabah dan bank secara musyawarah untuk mufakat. Hal tersebut tanpa mengurangi hak-hak bank sebagaimana diatur dalam akad murabahah di atas.

Terkait dengan klausal force majeure yang dicantumkan oleh para pihak di atas, para pihak telah sepakat untuk mengansurasikan objek yang dijaminkan tersebut pada PT Asuransi Umum Bumiputera Muda yang berkantor pusat di Jakarta (Pengelola). Pengelola memberikan ganti rugi kepada peserta dengan syarat-syarat pertanggungan mengacu standard asuransi kebakaran Indonesia sebagai berikut: ${ }^{37}$

Risiko yang dijamin:

Polis ini menjamin kerugian atau kerusakan pada harta benda dan atau kepentingan yang dipertanggungkan yang secara langsung disebabkan oleh:

a. Kebakaran

1) Yang disebabkan oleh kekurang hati-hatian atau kesalahan peserta atau pihak lain, atau sebab kebakaran lain sepanjang tidak dikecualikan dalam polis.

2) Yang disebabkan oleh:

a) Menjalarnya api atau panas yang timbul sendiri atau karena sifat barang itu sendiri;

b) Hubungan arus pendek;

c) Kebakaran yang terjadi karena kebakaran benda lain di sekitarnya dengan ketentuan benda lain tersebut bukan akibat dari risiko yang dikecualikan polis; termasuk juga kerusakan sebagai akibat dari air atau dan alat-alat lain yang dipergunakan untu memadamkan kebakaran dan atau dimusnahkannya seluruh atau sebagian harta benda kepentingan yang dipertanggungkan atas perintah yang berwenang dalam upaya menjalarnya kebakaran.

b. Petir

Kerusakan yang secara langsung disebabkan oleh petir. Khusus untuk mesin listrik, peralatan listrik atau elektronik dan instalasi listrik, kerugian atau kerusakan dijamin oleh polis ini apabila petir tersebut menimbulkan kebakaran pada benda-benda dimaksud.

c. Ledakan

1) Yang berasal dari harta benda yang dipertanggungkan pada polis ini atau polis lain yang berjalan serangkaian dengan polis ini untuk kepentingan peserta yang sama;

${ }^{37}$ Lihat Polis Standar Asuransi Kebakaran Indonesia (Syariah) (Pembiayaan) Ikhtisar Pertanggungan. 
2) Pengertian ledakan dalam polis ini adalah setiap pelepasan tenaga secara tiba-tiba yang disebabkan oleh mengembangnya gas atau uap;

3) Meledaknya suatu bejana (ketel uap, pipa dan sebagainya) dapat dianggap ledakan jika dinding bejan itu robek terbuka sedemikian rupa sehingga terjadi keseimbangan tekanan secara tiba-tiba di dalam maupun di luar bejana;

4) Jika ledakan itu terjadi dalam bejana sebagai akibat reaksi kimia, setiap kerugian pada bejana tersebut dapat diberikan ganti rugi sekalipun dinding bejana tidak robek terbuka;

5) Kerugian yang disebabkan oleh rendahnya tekanan di dalam bejana tidak dijamin oleh polis;

6) Kerugian pada mesin pembakar yang diakibatkan oleh ledakan dalam ruang pembakaran atau ledakan pada bagian tombol saklar listrik akibat timbulnya tekanan gas, tidak dijamin;

7) Dengan syarat apabila terhadap risiko ledakan ditutup juga pertanggungan dengan polis ini jenis lain yang khusus untuk itu, pengelola hanya menanggung sisa kerugian dari jumlah yang seharusnya dapat dibayarkan oleh polis jenis lain tersebut apabila polis ini dianggap seolah-olah tidak ada.

\section{Penutup}

Berdasarkan analisis di atas, penelitian ini menyimpulkan, pertama, kedudukan force majeure dalam akad murabahah sebagai suatu keharusan. Para pihak dalam akad murabahah tidak tertutup kemungkinan akan mengalami hal-hal atau peristiwa-peristiwa yang tidak dikehendaki dan membahayakan, yang berada di luar kuasa dari para pihak. Selain itu, Islam juga mengatur mengenai kedudukan yang mengarah kepada force majeure walaupun tidak secara langsung mengatur mengenai kata force majeure. Dalam hukum Islam force majeure dikenal dengan istilah dharurah, yang memiliki arti merusak atau memberi mudharat. Dalam istilah hukum Islam memberikan pengertian dharurah sebagai keadaan yang mendesak yang mengancam eksistensi manusia dan di luar kemampuan manusia, sehingga seseorang yang mengalami hal tersebut mendapatkan keringanan atau kemudahan sehingga memperbolehkan hal-hal yang dilarang untuk mengatasi keadaan dharurah tersebut.

Kedua, implementasi force majeure dalam akad murabahah pada Lembaga Keuangan Syariah pada prakteknya sudah diterapkan dalam akad atau perjanjian 
oleh para pihak. Klausula force majeure menjadi alasan untuk tidak membebankan kepada para pihak atas kerugian yang timbul akibat peristiwa force majeure yang terjadi. Sesuatu yang diperbolehkan karena kondisi dharurah, harus diselesaikan menurut batasan ukuran yang dibutuhkah tersebut. Sesuatu yang asalnya dilarang, lalu diperbolehkan lantaran keadaan yang memaksa, harus disesuaikan dengan ukuran dharurah yang sedang dideritanya, dan tidak boleh dinikmati sepuaspuasnya atau seenaknya saja. Kaidah ini memberikan batasan pada kemutlakan, dimana kebolehan yang terkandung di dalamnya hanya sekedar untuk menghilangkan kemudaratan yang sedang menimpa

Klausal force majeure harus dicantumkan dalam setiap akad yang dikeluarkan oleh para pihak agar dapat menyelamatkan para pihak dari peristiwa-peristiwa yang termasuk dalam kategori force majeure. Klausal force majeure tersebut diharapkan bisa menyelamatkan posisi para pihak dari tanggungan yang di luar dari kewajibannya yang disebabkan oleh peristiwa-peristiwa yang tak diinginkan.

\section{Daftar Pustaka}

\section{Buku}

Abd. Rahman, Zaharuddin, Figh Kewangan Islam, PTS Islamika, Malaysia, 2014.

Antonio, Muhammad Safii, Bank Syariah Dari Teori Ke Praktek, Gema Insani Press, Jakarta, 2001.

Arfan, H. Abbas, 99 Kaidah Fiqh Muamalah Kulliyah, Cetakan II, UIN Maliki Pers, Malang, 2013.

Ascarya, Akad \& Produk Bank Syariah, Raja Grafindo Persada, Jakarta, 2011.

Badrulzaman, Mariam Darus, Perjanjian Kredit Bank, Citra Aditya Bakti, Bandung, 1991.

Fuady, Munir, Hukum Perbankan Modern, Buku Kesatu, Citra Aditya Bakti, Bandung, 2003.

Rokamah, Ridho, Al-Qawaid Al-Fiqhiyah Kaidah-Kaidah Mengembangkan Hukum Islam, Stain Press, Ponorogo, 2010.

Satrio, J., Hukum Perikatan Perikatan pada Umumnya, Alumni, Bandung, 1999.

Susanto, Aspek-Aspek Hukum Perkreditan pada Bank, Jakarta, Alfabeta, 2003.

\section{Jurnal}

Lailiyah, Ashofatul, "Urgensi Analisa 5C pada Pemberian Kredit Bank untuk Meminimalisir Resiko", Yuridika, Vol. 29 No. 2 Mei-Agustus 2014. 
Purwanto, Harry, Keberadaan Asas Rebus Sic Stantibus Dalam Perjanjian Internasional, Jurnal Mimbar Hukum Edisi Khusus, November 2011.

Suhaeri, "Putusan Mahkamah Konstitusi Menghapus Rintisan Sekolah Bertaraf Internasional dalam Tinjauan Maqashid Syari'ah", Jurnal Konsitusi, Vol. 10 No. 2 Juni 2013.

\section{Peraturan Perundang-undangan}

Kitab Undang-Undang Hukum Perdata.

Undang-Undang Nomor 21 Tahun 2008 tentang Perbankan Syariah; Lembaran Negara Republik Indonesia Tahun 2008 Nomor 94.

Undang-Undang Nomor 21 Tahun 2011 tentang OJK; Tambahan Lembaran Negara Republik Indonesia Nomor 5253.

Peraturan Mahkamah Agung Republik Indonesia Nomor 02 Tahun 2008 tentang Kompilasi Hukum Ekonomi Syariah KUHPerdata.

Kompilasi Hukum Ekonomi Syari'ah.

Fatwa Dewan Syariah Nasional No 04/DSN-MUI/IV/2000 tentang Murabahah.

\section{Wawancara}

Hasil wawancara dengan Bapak Aryo Bramasto (ASO Account Officer) Bank BCA Syaiah KCU Yogyakarta, KCP Mangkubumi

Hasil wawancara dengan perwakilan Baitul Maal Wat Tamwil, Wates Kulonprogo Hasil wawancara dengan perwakilan PT Bank Pembiayaan Rakyat Syariah UNISIA Insan Indonesia, Yogyakarta

\section{Internet}

OJK, "Standar Produk Perbankan Syariah Murabahah", diakses dari https:/ / www.ojk.go.id/id/kanal/syariah/berita-dan-

kegiatan/publikasi/Documents/Pages/Buku-Standar-Produk-

Perbankan-Syariah-

Murabahah/Buku\%20Standar\%20Produk\%20Murabahah.pdf pada tanggal 13 Juli 2019 pukul 20 : 11 WIB 